\title{
THE LONG ASHTON RESEARCH STATION
}

\begin{abstract}
THE volume of work reported in Long Ashton's annual report* is now so large that some selection is necessary to keep a review within manageable proportions.

Growth of apple fruits is dependent on the presence of seeds, but D. L. Abbott finds that this is so only during seven weeks after petal fall. C. Bould worked on the nutritional aspects of fruit production and found that yield and growth responses of Royal Sovereign strawberries in relation to nitrogen, phosphate and potash were those to be expected from leaf analyses of non-manured plants at the fruiting stage. This should provide a useful practical approach to the vital question of soil nutrient needs. Pollination is a necessary factor in fruit production, and it is surprising that relatively little is known about the distance over which a pollinator variety is effective. R. R. Williams found it to be about $90 \mathrm{ft}$. in one orchard, but only $50 \mathrm{ft}$. in another. A survey by A. I. Campbell and R. R. Williams of eighty orchards in Hereford and Somerset shows that difficulties encountered in headworking cider apple trees are in part due to apple virus diseases. It is sometimes necessary to clear old tree-stumps from land; E. W. Hobbis and J. S. Coles have investigated various possible rotting agents-aqua regia, caustic soda, bleaching powder, and a nitrogen-phosphate fertilizer. Only the last material showed any effect after four years. Workers in the pomology section also discuss the technique of measuring the assimilation of radioactive carbon by leaves, a survey and descriptions of perry pear varieties, and the forecasting of harvest date in blackcurrant varieties from their flowering dates.
\end{abstract}

* Annual Report of the Agricultural and Horticultural Research Station (The National Fruit and Cider Institute), Long Ashton, Bristol, 1958. Pp. $190+18$ plates. (From the Station, 1959.) $15 s$ post paid.
A series of papers on spray application problems gives methods for the determination of spray residues -of gamma-BHC (J. A. Pickard), of microgram quantities of dieldrin (E. J. Skerrett and E. A. Baker), and of rotenone in Lonchocarpus (D. V. Richmond). A mercury content of 1 p.p.m. was found in coffee berries on trees which had received thirteen applications of mercury fungicide $(\mathrm{J} . \mathbf{A}$. Pickard and J. T. Martin). The plant cuticle is the immediate receptor for spray fluids, and J. T. Martin reviews current work on its nature and composition in several fruits and vegetable crops. Uptake of a fungicide (DMTD) by fungal spores (E. Somers), and the metabolism of certain aromatic compounds by fungi (D. Woodcock and R. J. W. Byrde) are also discussed. There has been quite a revolution in outlook on methods for spray application, and T. E. Cobbald briefly describes a prototype low-pressure twin-fluid atomizer. Fluorescent materials as tracers in spray liquids, and the vibrating jet method for the determination of dynamic surface tensions are two methods of assessing spray performance discussed in the report. Considerations of actual disease are mainly concerned with Gloesporium fruit rot, and entomology is represented by a paper on seasonal distribution of four species of leaf hoppers on apples. An interesting result of importance overseas is the finding of the fungus Trachysphaera fructigena on Jamaican bananas. The infection appears to have occurred in ripening rooms, from fruit from another source.

There are papers on cider and fruit juices and on domestic fruit preservation, as in previous years, and a list of 46 publications during 1958. It is announced in the introduction that the Agricultural Research Council's Unit of Plant Nutrition at Long Ashton was disbanded in September 1959. Members of its staff have, however, been absorbed into the work of the Station. JoHN GRAINGER

\section{INFLUENCE OF NITROGEN-CONTAINING BASES ON THE RATE OF THE ELECTRODE PROCESSES AT THE DROPPING MERCURY ELECTRODE}

\author{
BY Mrs. V. VOLKOVÁ \\ Polarographic Institute, Czechoslovak Academy of Sciences, Prague
}

\begin{abstract}
A SPECIFIC effect of gelatin, amines, $p$-aminobenzoic acid esters of amino-alcohols and nitrogen-containing heterocyclic compounds such as various pyridine derivatives, alkaloids, etc., has been found ${ }^{1,2}$ during the polarographic reduction of many organic compounds.

In respect of the polarographic waves, the effect on the reduction of substances capable of dissociation was of two kinds : on one hand, an influence on the height of the first wave, on the other hand, a considerable shift of the second wave to more positive potentials, often by several hundreds of millivolts.

The first case was observed chiefly with very weak acids, containing a heterocyclic nitrogen atom such as pyridine carboxylic acids, quinaldinic acid and oxyquinolines, and with corresponding aldoximes,
\end{abstract}

further with $\alpha$-Br-carboxylic acids, phthalic acid and benzaldehyde, the shift of the second wave being found with many reducible weak acids to such an extent that only a single wave was visible.

The effect on the first wave was originally explained by a reaction controlled by the recombination of the anion with the nitrogen-containing cation as protondonor ${ }^{1}$. The recombination-rate constants thus obtained were of the order $10^{8}-10^{10}$ except with atropine and some other alkaloids, where considerably larger values were obtained which depended on the concentration of the nitrogen compound.

Since the above-mentioned catalysts are substances of strongly adsorptive character, attention has been directed to the study of the role that this property takes in the problem studied. The conception of the 